\title{
FSH stimulation of the production of pyruvate and lactate by rat Sertoli cells may be involved in hormonal regulation of spermatogenesis
}

\author{
Nicolet H. P. M. Jutte, R. Jansen, J. A. Grootegoed, F. F. G. Rommerts \\ and $H$. J. van der Molen
}

Department of Biochemistry (Division of Chemical Endocrinology), Medical Faculty, Erasmus University Rotterdam, Rotterdam, The Netherlands

\begin{abstract}
Summary. Sertoli cells were obtained from 3-6-week-old rats, which were sterile after prenatal irradiation. The production of lactate by these Sertoli cells, measured 24-48 $\mathrm{h}$ after isolation during incubation in the absence of hormones, increased with age of the rats from 3 to 6 weeks. At all ages investigated, the production of lactate was enhanced in the presence of FSH plus testosterone, but the stimulation was most pronounced at 4 weeks of age. Lactate production was increased by FSH alone but testosterone had no effect in the presence or absence of FSH. Sertoli cells from 4-week-old rats produced both pyruvate and lactate, which accumulated in the incubation medium in a ratio of $1: 4$. The stimulation of the production of pyruvate and lactate by FSH was dosedependent $\left(\mathrm{ED}_{50}\right.$ at $\left.\sim 10 \mathrm{ng} \mathrm{NIH}-\mathrm{FSH}-\mathrm{S} 13 / \mathrm{ml}\right)$. The production of pyruvate and lactate was stimulated 2-fold by insulin, 4-fold by FSH and $>6$-fold by dibutyryl cyclic AMP (in the presence of 3-isobutyl-1-methylxanthine). The effects of FSH $(0.5 \mu \mathrm{g}$ $\mathrm{NIH}-\mathrm{FSH}-\mathrm{S} 13 / \mathrm{ml})$ and insulin $(5 \mu \mathrm{g} / \mathrm{ml})$ were not additive.

Leucine incorporation into isolated pachytene spermatocytes and round spermatids was stimulated by exogenous pyruvate and lactate in a dose-dependent way: maximal incorporation was obtained with $0.2 \mathrm{mM}$-pyruvate or $2 \mathrm{mM}$ L-lactate. Spent medium from incubated Sertoli cells (from 4-week-old rats) stimulated the leucine incorporation into isolated pachytene spermatocytes and round spermatids 4-8-fold. This effect could be explained by the amounts of pyruvate and lactate present in the spent medium. It is suggested that pyruvate and lactate are major products from Sertoli cells which can support synthetic activities in germ cells, and the present results indicate that pyruvate and lactate may play a role in the hormonal regulation of spermatogenesis.
\end{abstract}

\section{Introduction}

The initiation of spermatogenesis in mammalian testes is dependent on the presence of folliclestimulating hormone (FSH) and testosterone, and maintenance of spermatogenesis is largely obtained in the presence of testosterone (Steinberger, 1971; Fritz, 1978). It has been shown that these hormones exert direct effects on Sertoli cells, whereas it can be concluded from several observations that spermatocytes and spermatids are not target cells for FSH and testosterone (Grootegoed, Peters, Mulder, Rommerts \& van der Molen, 1977; Fritz, 1978). Hence, hormonal regulation of spermatogenesis appears to be mediated by Sertoli cells.

A possible nutritive role of Sertoli cells in germ cell development is supported by observations that Sertoli cells produce lactate at a high rate (Jutte, Grootegoed, Rommerts \& van der Molen, 
1981a; Robinson \& Fritz, 1981) and that pachytene spermatocytes and round spermatids require exogenous pyruvate or lactate to carry out energy requiring processes (Jutte et al., 1981a; Jutte et al., 1981 b; Mita \& Hall, 1982). Moreover, the rate of aerobic glucose utilization and production of lactate by Sertoli cells from immature rats was found to be increased during incubation in the presence of FSH (Jutte et al., 1982b; Jutte, Jansen, Grootegoed, Rommerts \& van der Molen, 1982a; Mita, Price \& Hall, 1982). The present experiments were performed to study the production of pyruvate and lactate by Sertoli cells in more detail with emphasis on the role of FSH during prepubertal development, and the effects of insulin. Many unknown components produced by Sertoli cells may be involved in germ cell development. Therefore, we also studied whether pyruvate and lactate, present in spent medium from Sertoli cells, are the most important factors that maintain activities in germ cells during short-term incubations.

\section{Materials and Methods}

Cell isolation. Germ cells were isolated from immature rats (Wistar, substrain R-Amsterdam, aged $30-35$ days, body weight $70-80 \mathrm{~g}$ ) by sedimentation at unit gravity as described previously (Jutte et al., 1982b). Two germ cell fractions were obtained: (a) a pachytene spermatocyte fraction, which contained mid-late pachytene spermatocytes $(80 \pm 9 \%)$, round spermatids $(4 \pm 3 \%)$, somatic cells $(1 \pm 1 \%)$, other germ cells and unidentified cells $(7 \pm 4 \%)$; and (b) a round spermatid fraction, which contained round spermatids $(81 \pm 9 \%)$, early spermatocytes $(7 \pm 4 \%)$, midpachytene spermatocytes $(6 \pm 4 \%)$, somatic cells $(1 \pm 1 \%)$, other germ cells and unidentified cells $(4 \pm 2 \%$ ) (mean \pm s.d., $n=13$ ). Sertoli cells were isolated from 3-6-week-old rats as described previously (Jutte et al., 1981a). The rats were irradiated in utero on Day 19 of gestation to obtain germ cell-depleted testes for the isolation of Sertoli cells not contaminated with germ cells (Beaumont, 1960). Following isolation, the germ cells and Sertoli cells were washed 3 times in incubation medium containing 3.3 mM-glucose (Jutte et al., 1981a).

Incubation conditions. Sertoli cells (about $300 \mu \mathrm{g}$ protein) were incubated for $24 \mathrm{~h} \mathrm{in} 2 \mathrm{ml}$ incubation medium (no pyruvate and lactate added) at $32^{\circ} \mathrm{C}$ under a humidified atmosphere of $5 \%$ $\mathrm{CO}_{2}$ in air, in the absence or presence of FSH $(5 \mu \mathrm{g} \mathrm{NIH-FSH-S} 12,1.25 \mathrm{U} / \mathrm{mg}$ or $0.5 \mu \mathrm{g}$ NIH-FSH$\mathrm{S} 13 / \mathrm{ml}, 15 \mathrm{U} / \mathrm{mg}$, gifts from the Endocrinology Study Section, NIH, Bethesda, Maryland, U.S.A.), testosterone $(200 \mathrm{ng} / \mathrm{ml})$, dibutyryl cyclic adenosine monophosphate (dbcAMP) $(0.5 \mathrm{~mm}), 3-$ isobutyl-1-methylxanthine (MIX, $25 \mu \mathrm{M})$ and insulin $(5 \mu \mathrm{g} / \mathrm{ml}$; Sigma, $26.8 \mathrm{U} / \mathrm{mg}$ ). The medium and additions were renewed after $24 \mathrm{~h}$ of incubation and the spent medium from the 24-48-h incubation period was collected, centrifuged at $1500 \mathrm{~g}$ for $10 \mathrm{~min}$ to remove a few unattached cells, and kept at $4^{\circ} \mathrm{C}$ for estimation of pyruvate and lactate. The attached and unattached cells were lysed in $1 \mathrm{M}-\mathrm{NaOH}$ and protein was estimated (Lowry, Rosebrough, Farr \& Randall, 1951). For some experiments twice the amount of Sertoli cells $(\sim 600 \mu \mathrm{g}$ protein) was incubated as described above to obtain spent medium (Sertoli-cell conditioned medium). Pachytene spermatocytes $(0.5 \times$ $10^{6}$ cells) or round spermatids $\left(10^{6}\right.$ cells) were incubated either in $0.5 \mathrm{ml}$ incubation medium plus $0.5 \mathrm{ml}$ Sertoli cell-conditioned medium or in $1 \mathrm{ml}$ incubation medium containing 0-2 mM-sodium pyruvate (Boehringer) or 0-4 mM-sodium DL-lactate (Sigma; about $50 \% \mathrm{~L}$-lactate) at $32^{\circ} \mathrm{C}$ under an humidified atmosphere of $5 \% \mathrm{CO}_{2}$ in air. Incorporation of $\left[{ }^{3} \mathrm{H}\right]$ leucine into cellular protein was estimated by incubation of germ cells for $2 \mathrm{~h}$ in the presence of $5 \mu \mathrm{Ci}\left[4,5-{ }^{3} \mathrm{H}\right] \mathrm{leucine}$ (final sp. act. $20.7 \mathrm{mCi} / \mathrm{mmol}$ ), following a preincubation of $30 \mathrm{~min}$. The incubations were terminated by addition of cold $0.9 \%(\mathrm{w} / \mathrm{v}) \mathrm{NaCl}$ (containing $7.6 \mathrm{~mm}$-leucine) and subsequently the amount of radioactivity incorporated into protein was estimated by precipitation of macromolecules with trichloroacetic acid (Jutte et al., 1981a, 1982b). The amounts of lactate and pyruvate in the media were estimated enzymically according to Hohorst (1970) and Czok \& Lamprecht (1970). Single estimations were performed for duplicate incubations for each condition. The data were statistically analysed with unpaired or paired (Text-fig. 5) Student's $t$ tests. 


\section{Results}

Production of lactate by Sertoli cells

From 3 to 6 weeks of age the testes of intact rats become populated with the more advanced germ cell types (pachytene spermatocytes, spermatids) which appear to require pyruvate or lactate. Therefore, we have studied the production of lactate by Sertoli cells isolated from 3-6-week-old rats. It is difficult to isolate Sertoli cells without germ cells from testes of intact rats, and preparations of Sertoli cells were therefore obtained from sterile (prenatally irradiated) rats. The Sertoli cells were incubated in chemically defined medium and lactate was estimated in the spent medium. The following results were obtained: (1) lactate production in the absence of hormones (basal production, expressed per mg of cell protein) was increased 4-fold from 3 to 6 weeks of age (Text-fig. 1); (2) lactate production by Sertoli cells from 3-6-week-old rats was increased during incubation in the presence of FSH plus testosterone (Text-fig. 1), but the ratio of stimulated to unstimulated secretion decreased with age as a result of the increased basal production; (3) testosterone did not increase the basal or FSH-stimulated lactate production by Sertoli cells from 4week-old rats (Jutte et al., 1982a, b) or from 6-week-old rats (Table 1). The effects of FSH were most pronounced in Sertoli cells from 4-week-old rats and therefore further experiments were performed using these Sertoli cells. The response to FSH of the production of both pyruvate and lactate by Sertoli cells from 4-week-old rats was dose-dependent (Text-fig. 2). Pyruvate and lactate were found in the spent incubation medium in a ratio of $1: 4$. This ratio was the same in the absence or presence of FSH. Half-maximal stimulation of the production of both pyruvate and lactate was obtained at approximately $10 \mathrm{ng} \mathrm{NIH}-\mathrm{FSH}-\mathrm{S} 13 / \mathrm{ml}$.

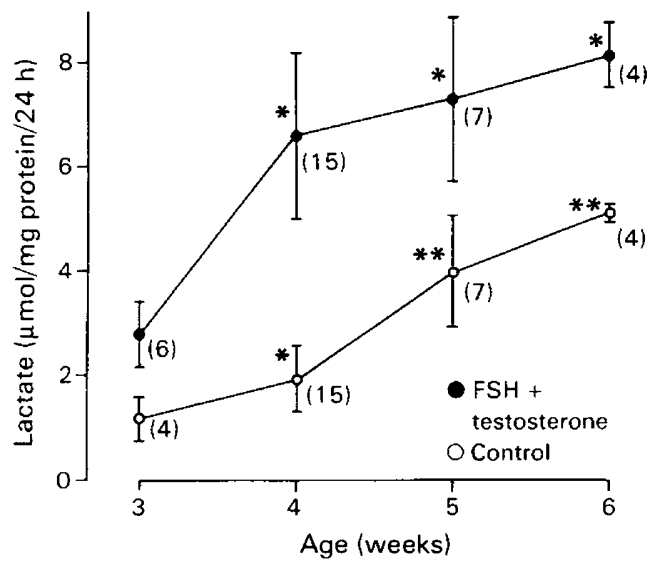

Text-fig. 1. Lactate production by Sertoli cells of rats of different ages. Sertoli cells obtained from prenatally irradiated rats of different ages were incubated for $24 \mathrm{~h}$ in chemically defined medium without further additions $(O)$ or in the presence of FSH $(7.5 \mathrm{NIH}-\mathrm{FSH}-\mathrm{S} 1 \mathrm{U} / \mathrm{ml})$ and testosterone $(200 \mathrm{ng} / \mathrm{ml})(O)$. Results represent means \pm s.d. for 4-15 different cell preparations (no. in parentheses). At all ages the amount of lactate in the spent medium was significantly higher after incubation in the presence of hormones $(P<0.01)$. ${ }^{*} P<0.05$ compared with value at 3 weeks. ${ }^{* *} P<0.05$ compared with value at 4 weeks.

Because insulin is involved in glucose metabolism, its effect on the production of pyruvate and lactate by Sertoli cells was investigated. The production of pyruvate and lactate by Sertoli cells from 4-week-old rats was stimulated 2-fold after $24-48 \mathrm{~h}$ of incubation in the presence of insulin, 


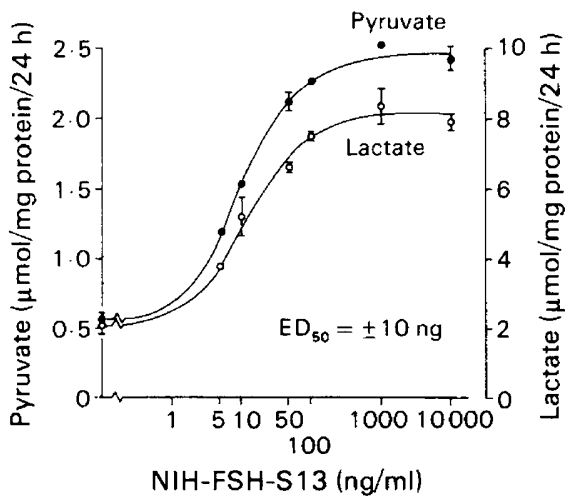

Text-fig. 2. FSH dose-response curve of pyruvate and lactate production by Sertoli cells from 4-week-old rats. Results represent means \pm range of duplicate incubations.

Table 1. Effects of testosterone and FSH on lactate secretion by Sertoli cells from 6-week-old rats

\begin{tabular}{lc}
\hline \multicolumn{1}{c}{ Treatment } & $\begin{array}{c}\text { Lactate secretion } \\
(\mu \mathrm{mol} / \mathrm{mg} \text { protein/24 h) }\end{array}$ \\
\hline No additions & $4.98 \pm 0.12$ \\
Testosterone & $5 \cdot 19 \pm 0.09$ \\
FSH & $8.05 \pm 0.25^{*}$ \\
FSH + testosterone & $8.06 \pm 0.71^{*}$ \\
\hline
\end{tabular}

The lactate secretion by Sertoli cells from 6-week-old rats was estimated as described in the legend to Text-fig. 1 . Results represent means \pm s.d. for 3 different cell preparations. Each cell preparation was tested in duplicate incubations.

* Significantly different from control and testosterone-treated Sertoli cells $(\boldsymbol{P}<0.01)$.

whereas a 4-fold stimulation was found in the presence of FSH plus testosterone (Text-fig. 3). Insulin did not further increase the rate of production of pyruvate and lactate obtained in the presence of FSH plus testosterone. Addition of dbcAMP plus the phosphodiesterase inhibitor MIX to isolated Sertoli cells stimulated the production of pyruvate and lactate 6-fold, indicating that the total capacity of Sertoli cells for production of pyruvate and lactate was larger than was evoked by FSH and insulin (Text-fig. 3).

\section{Effect of pyruvate and lactate on germ cells}

The stimulation of $\left[{ }^{3} \mathrm{H}\right]$ leucine incorporation into isolated pachytene spermatocytes and round spermatids by exogenous pyruvate and lactate was dose-dependent (Text-fig. 4). Pyruvate was effective at 10-fold lower concentrations than was lactate to support a high rate of leucine incorporation, since maximal leucine incorporation was reached at approximately 2 mM-L-lactate or $\mathbf{0 . 2}$ mM-pyruvate for pachytene spermatocytes and round spermatids during an incubation for $2 \mathrm{~h}$ in the presence of $3.3 \mathrm{~mm}$-glucose. Moreover, addition of both L-lactate $(3 \mathrm{or} 6 \mathrm{~mm})$ and pyruvate ( $2 \mathrm{mM})$ to spermatocytes and spermatids did not further increase the leucine incorporation above the level obtained by addition of pyruvate alone (results not shown). This indicates that 


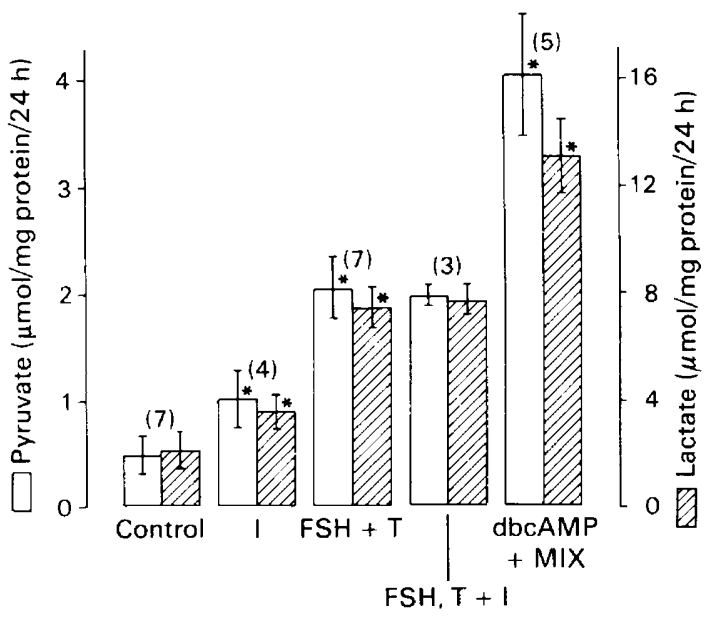

Text-fig. 3. Effects of insulin and dbcAMP on the production of pyruvate and lactate by Sertoli cells from 4-week-old rats. Sertoli cells were incubated in the presence or absence of insulin (I) $(5 \mu \mathrm{g} / \mathrm{ml})$, FSH $(0.5 \mu \mathrm{g} \mathrm{NIH-FSH}-\mathrm{S} 13 / \mathrm{ml})$, testosterone $(\mathrm{T})(200 \mathrm{ng} / \mathrm{ml})$ or dbcAMP $(0.5 \mathrm{mM})$ and MIX $(25 \mu \mathrm{M})$. Results represent means \pm s.d. for 3-7 different cell preparations (no. in parentheses). ${ }^{*}$ Values significantly different from the left-hand adjacent values $(P<0 \cdot 01)$.
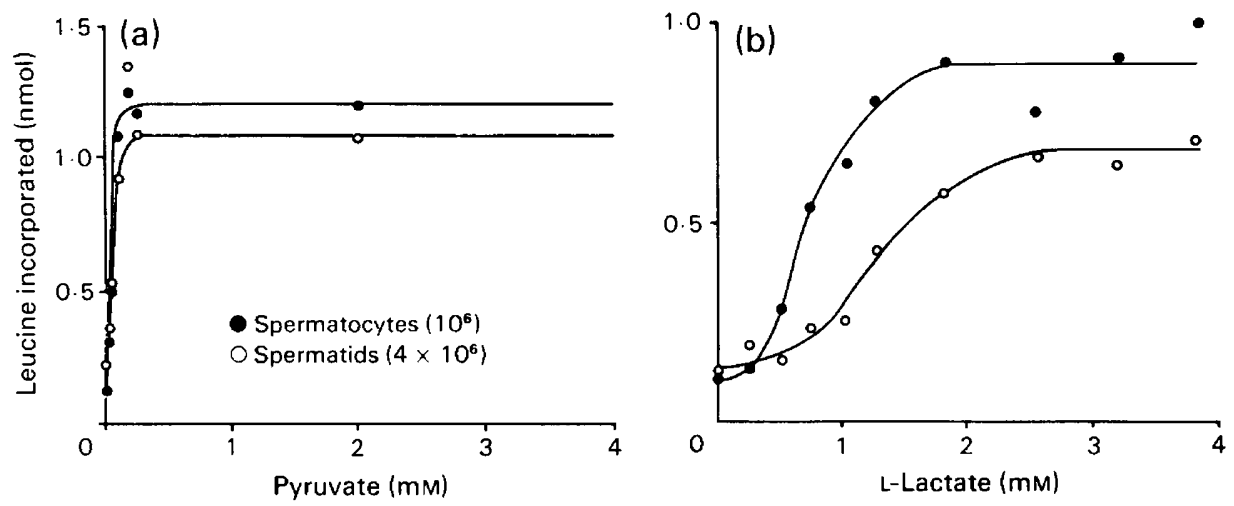

Text-fig. 4. Effect of (a) pyruvate and (b) lactate concentrations on the incorporation of leucine into isolated spermatocytes and spermatids. Isolated germ cells were incubated for $2 \mathrm{~h}$ in incubation medium containing different concentrations of pyruvate or lactate in the presence of $5 \mu \mathrm{Ci}$ [ ${ }^{3} \mathrm{H}$ ]leucine (final sp. act. $20.7 \mathrm{mCi} / \mathrm{mmol}$ ). Radioactivity incorporated into acidprecipitable material was estimated as described in 'Materials and Methods'. The total amount of leucine incorporated was calculated.

pyruvate, irrespective of the presence of lactate, can support a high rate of protein synthesis during short-term incubations.

\section{Effect of Sertoli cell-conditioned medium on germ cells}

To define the relative importance of pyruvate and lactate to germ cells, as compared to other products of Sertoli cells, the effect of spent medium from incubated Sertoli cells on germ cells was 


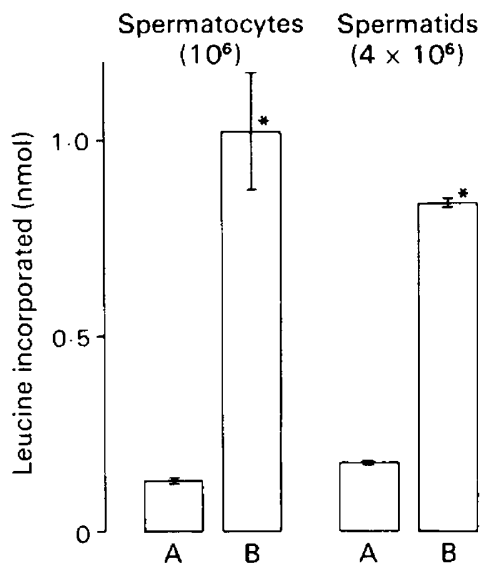

Text-fig. 5. Effect of Sertoli cell-conditioned medium on the incorporation of leucine into spermatocytes and spermatids. Sertoli cells from 4-week-old rats were incubated in the presence of NIH-FSH-S12 $(5 \mu \mathrm{g} / \mathrm{ml})$ and testosterone $(200 \mathrm{ng} / \mathrm{ml})$. Spent media from $24-48 \mathrm{~h}$ of incubation were collected (conditioned medium). Isolated germ cells were incubated for $2 \mathrm{~h}$ in fresh medium (A), or in a mixture of $0.5 \mathrm{ml}$ fresh medium plus $0.5 \mathrm{ml}$ Sertoli cell-conditioned medium (B). $\left[{ }^{3} \mathrm{H}\right]$ Leucine incorporation was measured as described in the legend to Text-fig. 4. Conditioned media from 3 different Sertoli cell preparations were tested on 6 different germ cell preparations (each germ cell preparation was tested in duplicate incubations) and the results are presented as means \pm s.d. $(n=3) .{ }^{*} P<0.01$ compared with value for $A$.

investigated. Isolated pachytene spermatocytes and round spermatids were incubated for $2 \mathrm{~h}$ in Sertoli cell-conditioned medium $\left(1: 1\right.$ diluted with fresh medium) and $\left[{ }^{3} \mathrm{H}\right]$ leucine incorporation into the cells was measured. The pmol amounts of incorporated leucine were calculated from the incorporated radioactivity, after correction for an increase of the specific radioactivity of leucine in the spent media, caused by leucine consumption by Sertoli cells. In the $1: 1$ diluted conditioned medium this leucine consumption may account for a 2-fold maximal increase of the specific radioactivity of leucine and this could result in a 2-fold maximal increase in incorporation of $\left[{ }^{3} \mathrm{H}\right]$ leucine into spermatocytes and spermatids incubated in this medium (results not shown). The incorporation of leucine into isolated pachytene spermatocytes and round spermatids incubated in conditioned medium was therefore 8- and 4-5-fold (uncorrected values 16- and 9-fold), respectively, higher than into germ cells incubated in fresh medium (Text-fig. 5). The concentrations of pyruvate and lactate in the Sertoli cell-conditioned medium (1:1 diluted with fresh medium) were respectively: $0 \cdot 16 \pm 0.04$ and $0.70 \pm 0.19 \mathrm{~mm}$ (mean \pm s.d. for 3 different cell preparations) at the start of the incubation with germ cells. From the dose-response curves (Text-fig. 4) it appears that these concentrations of pyruvate and lactate may account for the effect of Sertoli cell-conditioned media on protein synthesis in spermatocytes and spermatids.

\section{Discussion}

The results presented indicate that, among many components presumably present in spent medium from Sertoli cells, pyruvate and lactate are major products which act to maintain a high rate of protein synthesis in isolated spermatocytes and spermatids during short-term incubations. Moreover, pyruvate and lactate production by Sertoli cells were markedly stimulated by FSH, and it is therefore tempting to suggest that pyruvate and lactate may be involved in the effects of FSH on spermatogenesis. 
FSH and testosterone are involved in the initiation of spermatogenesis in immature rats or in restoration of a regressed germinal epithelium after long-term hypophysectomy in adult animals, whereas spermatogenesis in adult rats largely can be maintained by testosterone (Steinberger, 1971 ; Fritz, 1978). Stimulation of Sertoli cell activities by FSH was previously reported to decrease after 20 days of age (Dorrington, Fritz \& Armstrong, 1978; Fritz, 1978; Means et al., 1980). In our experiments, the effect of FSH on the production of lactate by Sertoli cells was most pronounced using Sertoli cells from 4-week-old rats and decreased at higher ages. This may be related to the above mentioned age-dependent pattern of hormonal stimulation of spermatogenesis. The absence of an effect of testosterone on the production of lactate by Sertoli cells from 4- and 6-week-old rats may indicate that glucose metabolism by Sertoli cells is not involved in the effect of testosterone on spermatogenesis. The results of the present short-term experiments, however, do not exclude that testosterone exerts a long-term effect on glucose metabolism by Sertoli cells in vivo.

If pyruvate and lactate are involved in the effects of FSH on spermatogenesis, the production of these compounds in the germinal epithelium should be a limiting factor for development of an optimal number of germ cells. The following variables may influence the amount of pyruvate and lactate present in the germinal epithelium in the absence of FSH.

(1) In vivo, transport of pyruvate and lactate from the blood into the seminiferous tubules may overshadow the contribution of Sertoli cells to the amount of these compounds in the fluid bathing the germ cells. As far as we know, no data are available on transport of pyruvate and lactate across the blood-testis barrier.

(2) At low levels of FSH, the production of pyruvate and lactate in vivo may be stimulated by insulin. It has previously been shown that insulin stimulates transferrin and ABP secretion by Sertoli cells from the older animals. On the other hand FSH stimulation of Sertoli cells in vivo may 1982). We observed that insulin did not further enhance the production of pyruvate and lactate when Sertoli cells were incubated in the presence of FSH. The possible long-term effects in vivo of FSH and insulin on carbohydrate metabolism by Sertoli cells need to be studied.

(3) The production of lactate by isolated Sertoli cells, incubated in the absence of FSH, was increased with age from 3 to 6 weeks. This may reflect a higher basal rate of glucose metabolism in Sertoli cells from the older animals. One the other hand FSH stimulation of Sertoli cells in vivo may be maintained during incubation, and the basal level of production of lactate measured in vitro may actually represent a stimulated level.

The production of pyruvate and lactate by Sertoli cells, and the ratio of pyruvate to lactate, may be dependent on many conditions which have an effect on cellular $\mathrm{NAD}^{+} / \mathrm{NADH}$ ratios through modulation of such processes as glucose utilization and citric acid cycle activity. To maintain protein synthesis of germ cells, pyruvate was effective at a 10-fold lower concentration than was lactate. From estimations of ATP levels in isolated round spermatids, it has been concluded that lactate was the preferred substrate for round spermatids (Mita \& Hall, 1982). This may be in contrast with the present results. However, it has been demonstrated that protein synthesis in spermatids was impaired at $37^{\circ} \mathrm{C}$ (Nakamura, Romrell \& Hall, 1978; Nakamura \& Hall, 1980) and the difference in the effects of pyruvate and lactate on protein synthesis (present results) and on ATP levels (Mita \& Hall, 1982) may be related to the effect of temperature. It seems that production of pyruvate by Sertoli cells is rate-limiting for activities of germ cells. However, it is not possible to predict the relative rates of pyruvate and lactate utilization under conditions in vivo. In the fluid bathing the germ cells in vivo, lactate may become the limiting substrate.

After hypophysectomy many spermatocytes and spermatids die (Clermont \& Morgentaler, 1955). It has been reported that after hypophysectomy the rate of development of a small number of surviving germ cells was not changed (Clermont \& Harvey, 1965). Moreover, RNA synthesis and processing was unaltered in a part of the population of advanced germ cells which survived for 2-4 days after hypophysectomy in immature rats (Grootegoed, van Meerkerk, Rommerts \& van der Molen, 1979). Such a quantitative effect on the number of developing germ cells may be related to a lack of substrate required for energy supply. In vivo, stimulation of Sertoli cells by FSH may 
maintain a high rate of substrate supply, so that development of a maximal number of germ cells can be supported. From the results presented, we conclude that the rate of pyruvate and lactate production by Sertoli cells may be involved in the hormonal regulation of spermatogenesis.

This work was supported in part by the Dutch Foundation for Medical Research (FUNGO). We thank Miss W. Bakhuizen for her help in the preparation of the manuscript.

\section{References}

Beaumont, H.M. (1960) Changes in the radiosensitivity of the testis during foetal development. Int. J. Radiat. Biol. 2, 247-256.

Clermont, Y. \& Harvey, S.C. (1965) Duration of the cycle of the seminiferous epithelium of normal, hypophysectomized and hypophysectomized, hormonetreated albino rats. Endocrinology 76, 80-89.

Clermont, Y. \& Morgentaler, H. (1955) Quantitative study of spermatogenesis in the hypophysectomized rat. Endocrinology 57, 369-382.

Czok, R. \& Lamprecht, W. (1970) Pyruvat, Phosphoenolpyruvate und D-Glycerat-2-Phosphat. In Methoden der enzymatische Analyse, 2nd edn, part II, pp. 14071411. Ed. H. U. Bergmeyer. Verlag Chemie GmbH, Weinheim.

Dorrington, J.H., Fritz, I.B. \& Armstrong, D.T. (1978) Control of testicular estrogen synthesis. Biol. Reprod. 18, 55-64.

Fritz, I.B. (1978) Sites of actions of androgens and follicle-stimulating hormone on cells of the seminiferous tubule. In Biochemical Actions of Hormones, Vol. 5, pp. 249-281. Ed. G. Litwack. Academic Press, New York

Grootegoed, J.A., Peters, M.J., Mulder, E., Rommerts, F.F.G. \& van der Molen, H.J. (1977) Absence of a nuclear androgen receptor in isolated germinal cells of rat testis. Molec. cell. Endocr. 9, 159-167.

Grootegoed, J.A., van Meerkerk, L.M., Rommerts, F.F.G. \& van der Molen, H.J. (1979) Effect of hypophysectomy on ribonucleic acid synthesis in primary spermatocytes isolated from rat testes. Int. J. Androl. 2, 330-342.

Hohorst, H.J. (1970) L-(+)-Lactat, Bestimmung mit Lactat-Dehydrogenase und NAD. In Methoden der enzymatische Analyse, 2nd edn, part II, pp. 14251429. Ed. H. U. Bergmeyer. Verlag Chemie GmbH, Weinham.

Jutte, N.H.P.M., Grootegoed, J.A., Rommerts, F.F.G. \& van der Molen, H.J. (1981a) Exogenous lactate is essential for metabolic activities in isolated rat spermatocytes and spermatids. J. Reprod. Fert. 62, 399-405.

Jutte, N.H.P.M., Koolen, L.M., Jansen, R., Grootegoed, J.A., Rommerts, F.F.G. \& van der Molen, H.J. (1981b) Lactate essential for biochemical activities in isolated germinal cells. Int. J. Androl., Suppl. 3, 59, Abstr.
Jutte, N.H.P.M., Jansen, R., Grootegoed, J.A., Rommerts, F.F.G. \& van der Molen, H.J. (1982a) Regulation of survival of germ cells by lactate supply from Sertoli cells. Annls N.Y. Acad. Sci. 383, 469, Abstr.

Jutte, N.H.P.M., Jansen, R., Grootegoed, J.A., Rommerts, F.F.G., Clausen, O.P.F. \& van der Molen, H.J. (1982b) Regulation of survival of rat pachytene spermatocytes by lactate supply from Sertoli cells. $J$. Reprod. Fert. 65, 431-438.

Karl, A.F. \& Griswold, M.D. (1980) Actions of insulin and vitamin A on Sertoli cells. Biochem. J. 186, 10011003.

Lowry, O.H., Rosebrough, N.H., Farr, A.L. \& Randall, R.J. (1951) Protein measurement with the Folin phenol reagent. J. biol. Chem. 193, 265-275.

Means, A.R., Dedman, J.R., Tash, J.S., Tindall, D.J., van Stickle, M. \& Welsh, M.J. (1980) Regulation of the testis Sertoli cell by follicle-stimulating hormone. Ann. Rev. Physiol. 42, 59-70.

Mita, M. \& Hall, P.F. (1982) Metabolism of round spermatids from rats: lactate as the preferred substrate. Biol. Reprod. 26, 445-455.

Mita, M., Price, J.M. \& Hall, P.F. (1982) Stimulation by follicle-stimulating hormone of synthesis of lactate by Sertoli cells from rat testis. Endocrinology 110, 15351541 .

Nakamura, M. \& Hall, P.F. (1980) The mechanism by which body temperature inhibits protein biosynthesis in spermatids of rat testes. J. biol. Chem. 255, 29072913.

Nakamura, M., Romrell, L.J. \& Hall, P.F. (1978) The effects of temperature and glucose on protein biosynthesis by immature (round) spermatids from rat testes. J. Cell Biol. 79, 1-9.

Robinson, R. \& Fritz, I.B. (1981) Metabolism of glucose by Sertoli cells in culture. Biol. Reprod. 24, 10321041 .

Skinner, M.K. \& Griswold, M.D. (1982) Secretion of testicular transferrin by cultured Sertoli cells is regulated by hormones and retinoids. Biol. Reprod. 27, $211-221$.

Steinberger, E. (1971) Hormonal control of mammalian spermatogenesis. Physiol. Rev. 51, 1-22.

Received 8 October 1982 